\title{
BMJ Open Quality Applying lean improvement methodology within a public health context: administration and organisation of a training programme
}

\author{
Elisabeth Smart, Valerie MacDonald, Cameron Stark, Lynda Thomson, \\ Hugo van Woerden
}

To cite: Smart E, MacDonald V, Stark C, et al. Applying lean improvement methodology within a public health context: administration and organisation of a training programme. BMJ Open Quality 2018;7:e00257. doi:10.1136/ bmjoq-2017-000257

Received 17 November 2017 Revised 31 July 2018 Accepted 11 August 2018
Check for updates

(c) Author(s) (or their employer(s)) 2018. Re-use permitted under CC BY-NC. No commercial re-use. See rights and permissions. Published by BMJ.

Department of Public Health, NHS Highland, Inverness, UK

Correspondence to Elisabeth Smart elisabeth.smart@nhs.net

\section{PROBLEM}

The Health Improvement team, housed within the Public Health Department of National Health Service (NHS) Highland, deliver key objectives around health improvement, tackling health inequalities and building capacity. The processes surrounding the delivery of the building capacity objective had been built up over a period of time and historically were administered by different staff members. This led to different ways of organising training and no overall agreed approach.

The impact of a non-standard approach meant that it was often difficult to get an overview of what was being delivered and who was attending the various training offered. Furthermore, there were duplicate processes in place that were person dependent that could be done in a more effective way. Our overall aim for the project was to introduce a standard approach to how training
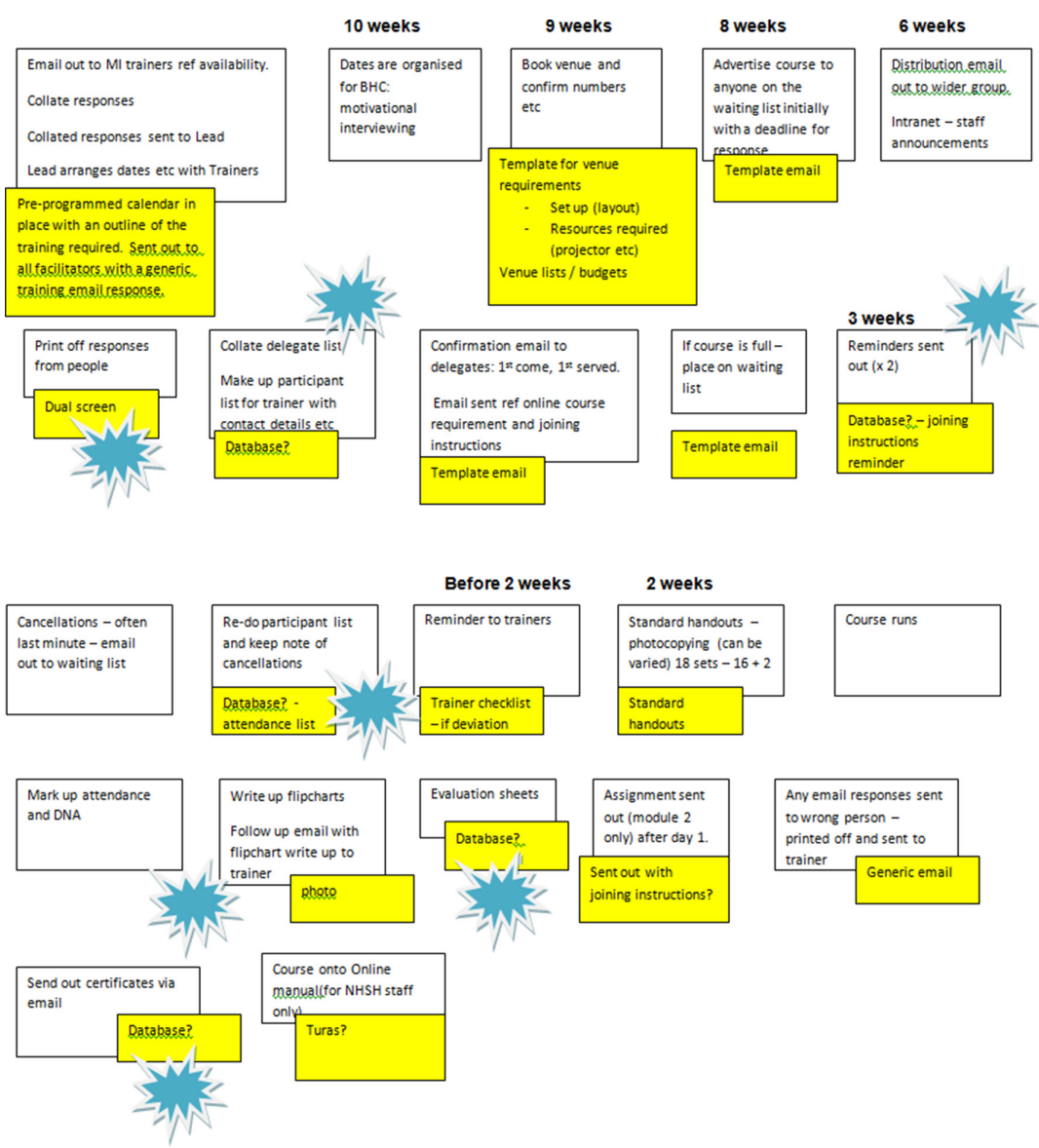

Figure 1 Current state administrative training processes. BHC, behaviour change; MI, motivational interviewing; NHSH, National Health Service Highland. 
was organised and a way of ensuring that data could be collected and reviewed instantly so that we could report out on a monthly basis. ${ }^{1}$

\section{METHOD}

We began by applying a tool called process mapping, ${ }^{2}$ which sets out the steps that take place within any specific function. The particular function that we looked at was organising and booking the health improvement motivation interviewing training.

Once the map was completed, it is then interrogated in order to understand why some of the steps were required and whether there is any duplication (non-value-added waste). See figure 1.

Following on from this, we mapped out what a desired process or future state might look like and developed standard work. ${ }^{3}$ We tested out the standard work with two members of staff initially and amended accordingly before applying it further. See figure 2 .

We also tested out using a PDSA (Plan, Do, Study, Act) cycle the introduction of a standard evaluation tool in order to compare results across different training courses delivered.

By carrying out observations, it was apparent that staff were recording information in different ways which

\begin{tabular}{|c|c|c|}
\hline \multirow{3}{*}{$10-12$ weeks } & Dates and details of training passed to admin team & \\
\hline & $\begin{array}{l}\text { Standard template email sent out to venue/s ref } \\
\text { availability }\end{array}$ & $\begin{array}{l}\text { Standard template: } \\
\text { venue request }\end{array}$ \\
\hline & $\begin{array}{l}\text { Once venue confirmed-add to pecos and update } \\
\text { on training calendar. }(H>H P D \text { training }>\text { course calendars } \\
\text { ग017-18) }\end{array}$ & \\
\hline \multirow[t]{2}{*}{9 weeks } & $\begin{array}{l}\text { Standard template with Purchase order attached } \\
\text { ref layout of room and resources required. }\end{array}$ & $\begin{array}{l}\text { Standard template: layout of } \\
\text { room and resources or } \\
\text { booking form completed }\end{array}$ \\
\hline & $\begin{array}{l}\text { Course details are loaded onto database - including } \\
\text { dates, venue, course title and trainer }\end{array}$ & \\
\hline 8 weeks & $\begin{array}{l}\text { Course details using standard template email is sent } \\
\text { to waiting list with relevant details of course }\end{array}$ & $\begin{array}{l}\text { Standard email: } \\
\text { Waiting list }\end{array}$ \\
\hline \multirow[t]{3}{*}{6 weeks } & $\begin{array}{l}\text { Course details using standard template email is sent } \\
\text { to distribution list and advertise on intranet. (with } \\
\text { flyer and application form) }\end{array}$ & $\begin{array}{l}\text { Standard email: } \\
\text { Course details to } \\
\text { distribution list }\end{array}$ \\
\hline & $\begin{array}{l}\text { Returned application forms loaded onto database } \\
\text { as they are received and relevant confirmation } \\
\text { email with joining instructions issued }\end{array}$ & $\begin{array}{l}\text { Standard email: } \\
\text { Confirmation email }\end{array}$ \\
\hline & $\begin{array}{l}\text { Once course is filled, standard template email sent } \\
\text { to those who will be on the waiting list and details } \\
\text { added onto database }\end{array}$ & $\begin{array}{l}\text { Standard email: } \\
\text { Course fully booked }\end{array}$ \\
\hline \multirow[t]{2}{*}{3 weeks } & Reminder email sent out & $\begin{array}{l}\text { Standard email: } \\
\text { reminder }\end{array}$ \\
\hline & $\begin{array}{l}\text { Cancellations noted on the database and people on } \\
\text { waiting list for course alerted. }\end{array}$ & $\begin{array}{l}\text { Standard email: if space } \\
\text { becomes available }\end{array}$ \\
\hline 2 weeks & Standard handouts produced ready for course start & \multirow[b]{2}{*}{$\begin{array}{l}\text { Course cancellation if } \\
\text { required-standard } \\
\text { email issued }\end{array}$} \\
\hline 1 week | & $\begin{array}{l}\text { Participant list with contact details printed off from } \\
\text { database and copy given to trainer }\end{array}$ & \\
\hline \multirow{2}{*}{ After course } & Participant list returned to admin once course has & $\begin{array}{l}\text { Trainer specific follow up if } \\
\text { required. }\end{array}$ \\
\hline & run and details noted on the database & $\begin{array}{l}\text { DNA email issued to those } \\
\text { who did not attend with } \\
\text { no notification. }\end{array}$ \\
\hline
\end{tabular}

Figure 2 Future state training administration - flowchart. HPD, Health Promotion Department. 
resulted in duplication of work. To improve the process, we developed a database which set out agreed steps for all administration staff about how a course should be managed. The database records all the information in one place and enables instant reporting of numbers of attendees, role and location of courses.

The success of the training programme is underpinned by access to and use of training resources. Observations showed that staff had developed their own resources, and these were often housed in different places making it difficult to locate the desired items. Furthermore, this led to poor stock control. We used a lean tool called $5 \mathrm{~S},{ }^{4}$ which consists of five different stages in ensuring resources are effectively managed. The five steps consist of sort, simplify, sweep, standardise and self-discipline. The photographs below illustrate an example of how the resources were managed before we began the process and the results after we applied 5S. See figures 3 and 4 .

Stock control was improved for three standard training packs by introducing a kanban inventory control system of cards that outlined the information needed when re-ordering items. This has resulted in timely restocking and less waste as we now only order items needed.

\section{RESULTS}

We collected measurements (table 1) before we applied the lean tools that demonstrated it took between 4 and 5 days to find the information and then produce

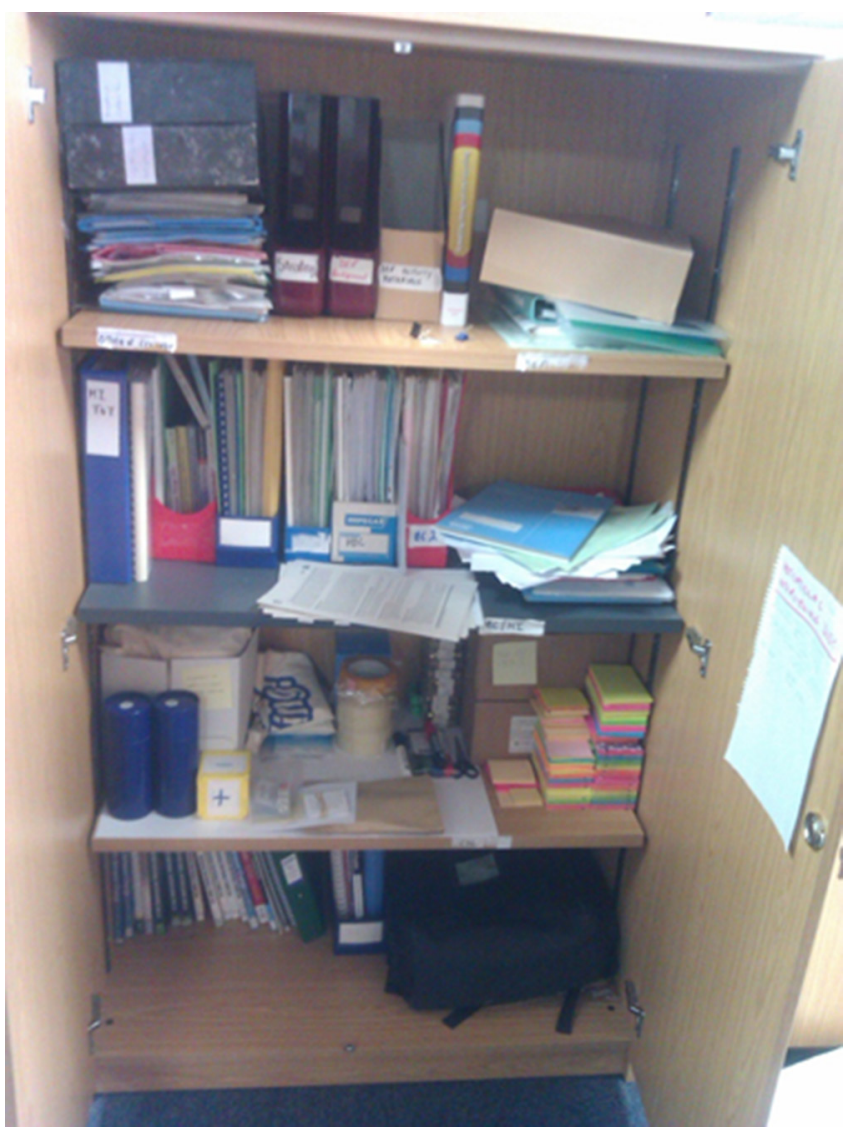

Figure 3 Before the 5S process was applied. a training activity report. With the new capacity of the database, a report can be generated in minutes. We estimated that we were able to reduce the length of time taken in organising a course from 2 hours to 1 hour. This allowed the team to reallocate the time saved in administration to other health improvement programmes. The staff delivering training and staff involved in the administration were often being asked to organise training at the last minute resulting in additional pressure. By introducing a standard operating procedure (SOP), which included the minimum notice required for staff, this was breached on one occasion only within the test period.

Other metrics, showing an improvement, included training requests being 10 weeks in advance of the start date and a reduction in length of time spent in organising the training. The $5 \mathrm{~S}$ audit was also included in the metric sheet.

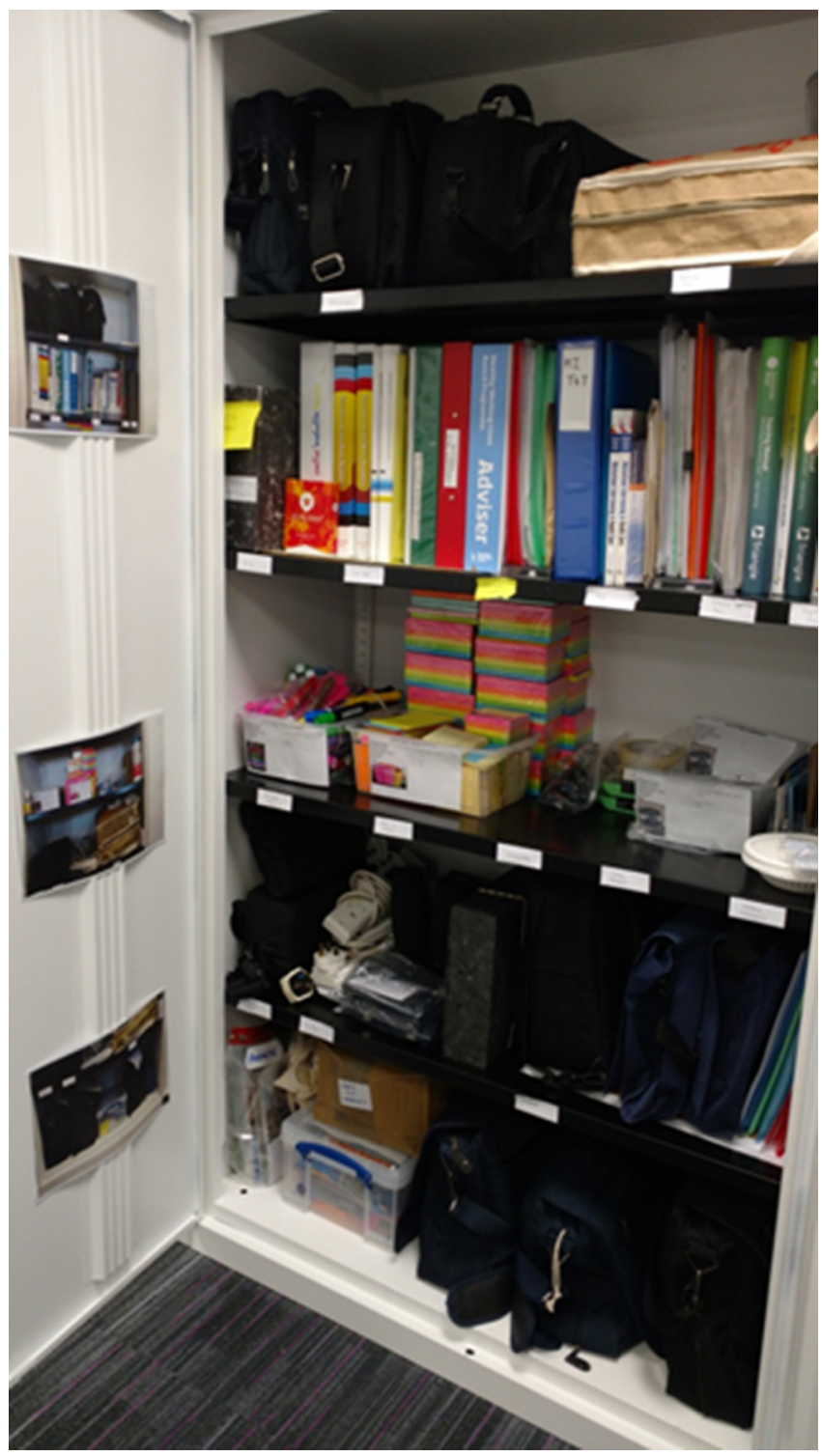

Figure 4 After the 5 S process was applied. 
Table 1 Metrics training programme

\section{Intermediate lean training Improvement project measurement}

\begin{tabular}{|c|c|c|c|c|c|c|}
\hline \multicolumn{2}{|c|}{$\begin{array}{l}\text { Title: Applying Improvement Methodology within } \\
\text { a Public Health Context }\end{array}$} & \multicolumn{2}{|c|}{$\begin{array}{l}\text { Date of reporting: } \\
26 \text { May } 2017\end{array}$} & \multicolumn{2}{|c|}{$\begin{array}{l}\text { Report by: } \\
\text { team leaders }\end{array}$} & Change against baseline \\
\hline & \multicolumn{5}{|l|}{ PDSA cycles } & \\
\hline $\begin{array}{l}\text { Length of time to collate training } \\
\text { data }\end{array}$ & $4-5$ days & & $30 \mathrm{~min}$ & & $30 \mathrm{~min}$ & $\begin{array}{l}98.3 \% \text { reduction } \\
\text { (4 days) }\end{array}$ \\
\hline $\begin{array}{l}\text { Training requests sent to } \\
\text { administration } 10 \text { weeks in } \\
\text { advance of training taking place }\end{array}$ & \multicolumn{2}{|c|}{$\begin{array}{l}50 \%-60 \% \text { of courses } \\
\text { requested less than } \\
10 \text { weeks' notice }\end{array}$} & \multicolumn{2}{|c|}{$\begin{array}{l}90 \% \text { compliance within } \\
\text { first month of testing }\end{array}$} & $\begin{array}{l}90 \% \text { compliance within } \\
\text { first month of testing }\end{array}$ & $\begin{array}{l}40 \%- \\
60 \% \text { increase }\end{array}$ \\
\hline $\begin{array}{l}\text { Reduction in length of time taken } \\
\text { in organising training }\end{array}$ & \multicolumn{2}{|c|}{$\begin{array}{l}2 \text { hours administration } \\
\text { time per course }\end{array}$} & 1 hour 30 & & 1 hour & $50 \%$ reduction \\
\hline
\end{tabular}

PDSA, Plan, Do, Study, Act.

\section{CONCLUSIONS}

Lean is about identifying value-added activity and non value activity in systems and ensuring that in eliminating the waste, we can operate in a much more efficient manner. The application of lean within a Public Health context was less well known; however, this project demonstrates that lean can be as easily applied to processes within public health as to a clinical setting. Furthermore, given the pressures on NHS budgets it is vital that Health Improvement programmes are run as efficiently as possible. We estimated that by introducing these improvement tools, we saved $25 \%$ of each hour spent on the training administration at a cost of $£ 9.38$ per hour (Agenda for Change), which was then reallocated to support other work. The introduction of a SOP is key to sustaining this work. The next steps are to apply our learning in larger-scale pieces of health improvement work.

Acknowledgements Thank you to VMacD and LT from the NHS Highland Health Improvement team who saw the potential of applying improvement methods to the project and to Tanzeela Bashir for administrative support. CS, Consultant in Public Health, provided lean training and ongoing support.
Contributor ES: co-ordinated all contributions and edited report. CS: advice and guidance in relation to content and support with referencing. VMacD: planned and delivered the project; supported the writing. LT: planned, delivered the project and wrote and edited the report. HvanW: advice, encouragement and guidance in relation to publishing.

Funding The authors have not declared a specific grant for this research from any funding agency in the public, commercial or not-for-profit sectors.

Competing interests None declared.

Provenance and peer review Not commissioned; externally peer reviewed.

Open access This is an open access article distributed in accordance with the Creative Commons Attribution Non Commercial (CC BY-NC 4.0) license, which permits others to distribute, remix, adapt, build upon this work non-commercially, and license their derivative works on different terms, provided the original work is properly cited, appropriate credit is given, any changes made indicated, and the use is non-commercial. See: http://creativecommons.org/licenses/by-nc/4.0/.

\section{REFERENCES}

1. Kenney C. Transforming health care: Virginia Mason Medical Centre's pursuit of the perfect patient experience: Productivity Press, 2010.

2. Damiello R. The basics of process mapping. 2nd edn. New York: Productivity Press, 2011.

3. Jackson TL. Standard work for lean healthcare. Boca Raton: CRC Press, 2012.

4. Productivity Press Development Team. 5S for operators. New York: Productivity Press, 1996. 